\title{
Barriers to addiction prevention and treatment in communities with organized crime: the perspective of health providers
}

\author{
Anel Hortensia Gómez San Luis,' Ariagor Manuel Almanza Avendaño’
}

\begin{abstract}
Unidad Académica de Trabajo Social y Ciencias para el Desarrollo Humano, Universidad Autónoma de Tamaulipas, Ciudad Victoria, Tamaulipas, México.
\end{abstract}

\section{Correspondence:}

Anel Hortensia Gómez San Luis Unidad Académica de Trabajo Social y Ciencias para el Desarrollo Humano, Universidad Autónoma de Tamaulipas-Campus Universitario Adolfo López Mateos.

A.P. 476, C.P. 87149 . Ciudad Victoria, Tamaulipas, México.

Phone: 5551935437

Email: anelgomezsanluis@gmail.com

Received: 12 May 2017 Accepted: 2 February 2018

\section{Citation:}

Gómez San Luis, A. H., Almanza Avendaño, A. M. Barriers to addiction prevention and treatment in communities with organized crime: the perspective of health providers. Salud Mental, $47(2), 73-80$ doi: 10.17711/SM.0185-3325.2018.010

\section{cc) (i) (5)}

\begin{abstract}
Introduction. The presence of organized crime may encourage an increase in the supply of illicit substances, the incorporation of young people into crime, the promotion of substance-oriented lifestyles, and the use of violent tactics to control territories that generate insecurity and loss of social capital are generated. Objective. The purpose of this study is to determine the barriers related to the presence of organized crime for the prevention and treatment of addictions from the perspective of health staff. Method. Based on a grounded theory study, eight semi-structured focused interviews were conducted with the staff of a primary addiction care center. In the interviews, the characteristics of the center, type of services, user profiles, the most successful treatments and barriers to care were explored, emphasizing those related to the presence of organized crime in the community. The data obtained were subjected to a thematic analysis with the help of MAXQDA software version 12. Results. Thematic analysis shows that criminal organizations determine which substances are used, encourage distribution within educational contexts, establish control processes in communities, limit preventive actions and treatments, and promote lifestyles associated with consumption, which especially affect vulnerable young people at the familial, social, and economic level. Discussion and conclusion. Membership of organized crime is also linked to substance use, so those affected seek treatment in spaces where there are insufficient safety conditions and health providers to create personal strategies for their protection. The article concludes that addiction prevention implies the recovery of communities and educational spaces by state institutions, while care requires better safety conditions for users and health staff.
\end{abstract}

Keywords: Substance related-disorders, health care delivery, health personnel, crime, drug trafficking

\section{RESUMEN}

Introducción. La presencia del crimen organizado favorece el aumento de la oferta de sustancias ilícitas, la incorporación de jóvenes en la delincuencia, la promoción de estilos de vida orientados al consumo de sustancias y el uso de tácticas violentas para controlar territorios que generan inseguridad y pérdida de capital social. Objetivo. Conocer las barreras relacionadas con la presencia del crimen organizado para la prevención y el tratamiento de las adicciones desde la perspectiva del personal de salud. Método. A partir de un estudio de teoría fundamentada, se realizaron ocho entrevistas semi-estructuradas focalizadas al personal de un centro de atención primaria en adicciones. En las entrevistas se exploraron las características del centro, el tipo de servicios, el perfil de los usuarios, los tratamientos más exitosos y las barreras para la atención, haciendo énfasis en las vinculadas con la presencia del crimen organizado en la comunidad. Los datos obtenidos se sometieron a un análisis temático con ayuda del software MAXQDA versión 12. Resultados. El análisis temático muestra que las organizaciones delictivas determinan las sustancias que se consumen, favorecen la distribución dentro de contextos educativos, establecen procesos de control en las comunidades, limitan las acciones preventivas y los tratamientos, y promueven estilos de vida asociados al consumo, todo lo cual afecta especialmente a jóvenes vulnerables en el ámbito familiar, social y económico. Discusión y conclusión. En comunidades donde hay crimen organizado, las instituciones que brindan tratamiento no cuentan con condiciones de seguridad, por lo que el personal de salud requiere generar estrategias personales para su protección. La prevención de las adicciones implica la recuperación de las comunidades y espacios educativos por parte de las instituciones del estado, mientras que la atención requiere mejores condiciones de seguridad para los usuarios y el personal de salud.

Palabras clave: Trastornos relacionados con sustancias, atención de la salud, personal de salud, crimen, tráfico de drogas. 


\section{INTRODUCTION}

Addiction treatment is usually affected by structural determinants of health such as social inequality or cultural values and norms (World Health Organization [WHO], 2009; Solar \& Irwin, 2010). Several barriers affecting this process have been reported in the literature, such as the delay for the first contact with health services (Borges, Wang, Medina-Mora, Lara, \& Chiu, 2007), limitations on access to treatment due to gender, socioeconomic position, and migratory status or prison (Guerrero et al., 2014; Romero, Saldívar, Loyola, Rodríguez, \& Galván, 2010), as well as cultural beliefs about addiction and its construction as a "vice", which influence the identity of the user, the way the problem is addressed at the individual and family level, and even the relationship with health services (Natera, Mora, \& Tiburcio, 1999; Nuño-Gutiérrez, Álvarez-Nemegyei, González-Forteza, \& Madrigal-de León, 2006).

In terms of treatment, more interventions are required to reduce illicit substance use (Rojas, Real, García-Silberman, \& Medina-Mora, 2011) and barriers have been found for the adoption of evidence-based practices such as the lack of sufficient trained clinical staff and the need for multidisciplinary teams (Horigian et al., 2016). Likewise, in some detention centers, violations of users' rights and low service quality have been identified (Marín-Navarrete et al., 2013).

However, there are other elements that can affect both addiction prevention and treatment in local contexts, such as the presence of organized crime. In particular, organizations linked to illicit drug trafficking affect the social and economic development of countries due to the rationalized use of violence and the corruption links established with the state (Silva, 2004), the emergence of health problems, decrease in productivity, diversion of economies towards activities such as money laundering (Singer, 2008) and the incorporation of young people into crime (Vázquez, 2012).

In recent years, in Mexico these groups have used violent tactics with multiple purposes: acquiring and controlling territories, limiting rival organizations, creating an atmosphere of censorship, degrading public institutions, or inducing their cooperation (Dulin \& Patiño, 2014). In communities affected by violence associated with the "war against organized crime," everyday routines are altered (Vilalta, 2016) and the destruction of social, economic, and cultural capital is encouraged (Hernandez \& Grineski, 2012).

Organized crime also plays a fundamental role in the supply of illicit substances (Richter-White, 2002), the promotion of values and lifestyles related to substance use in certain social groups (Reyes-Sosa, Larrañaga-Egilegor, \& Valencia-Garate, 2015), and the modification of the forms of access to substances and consumer practices (Gómez \& Almanza-Avendaño, 2016). However, the specific ways in which the presence of organized crime constitutes a barrier to addictions prevention and treatment have not been studied.
The purpose of this study is therefore to determine the barriers related to the presence of organized crime for addiction prevention, and treatment from the perspective of health staff.

\section{METHOD}

\section{Characteristics of the research team}

The interviews were conducted by the first author of this work, a psychologist with clinical training in systemic therapy and experience in the qualitative research of social phenomena such as drug trafficking and addictions. At the time of the study, she was working as a researcher at a higher education institution, so she had had no previous relationship with the participants. It should be noted that once the fieldwork had been completed, there was no further communication with the participants. The second researcher, a psychologist with clinical experience and social research, did not undertake the field work, and instead focused on the critical review of the instrument and the data analysis.

\section{Type of study}

Knowledge about the way organized crime hinders addiction prevention and care is limited. Accordingly, a grounded theory study was carried out. Since grounded theory is based on data, it is more likely to generate knowledge, increase understanding, and provide meaningful guidance for action (Corbin \& Strauss, 2008). The underlying aim is to build an integrated set of theoretical concepts from empirical data, and not only to synthesize and interpret the data but also to uncover procedural relationships (Charmaz, 2013).

\section{Participants}

Purposive sampling by criterion was used (Patton, 1990). The criterion consisted of being a health professional and working in addiction prevention and/or treatment. The participants were eight women psychologists, who performed activities including both outside prevention and outpatient treatment of users with substance abuse problems. Their ages fluctuated between 25 and 31, and the time they had been affiliated to the institution ranged from one to nine years. It should be noted that there were no male staff members at the center.

\section{Location}

The research was conducted at a primary addiction care center in the state of Tamaulipas; the name of the municipality is omitted for safety reasons. The center is located in a strategic district for the early detection of vulnerable 
people and experimental users. The schools located in the community are considered at risk, not only for consumption, but also because of the presence of organized crime (involving the sale and trafficking of illicit substances) in the community. For these reasons it was considered an ideal setting for undertaking the research.

\section{Instrument}

A focused semi-structured interview guide (Flick, 2004) was developed to explore the following topics: characteristics of the center (programs, activities, and treatments, as well as the profile of the health providers that works there); user profile (age, sex, socioeconomic status, family status, most frequently used substances, and problems associated with use); good user care practices (strategies and treatments that reduce consumption), and difficulties identified in the care process (prevention and treatment barriers, with particular emphasis on those attributable to the presence of organized crime in the community).

The interview guide was prepared by the first author of this work and presented for critical review to the second author, who contributed specific questions to explore each of the topics in the interview. During the construction and revision of the instrument, the criteria suggested by Flick (2004) for the semi-structured interview were considered: lack of direction in the questions to avoid influencing the answers, specificity of topics in order to explore them with sufficient depth and breadth to address all the issues or relevant aspects related to the object of study, and depth and personal context of the participants to achieve sufficiently descriptive answers about the participants experience.

It was decided to begin the interview with a neutral topic, "characteristics of the center," because in addition to reflecting the immediate environment in which the health providers works, it is a good topic to lead into the central topic of the interview without making the participants feel threatened. The decision to continue with the exploration of the "user profile" responds to the need to know the sociodemographic characteristics, particularly the users' proximity to or possible participation in organized crime (the questions about the substances they use and the problems related to use sought to explore the way they obtain access to substances and their possible engagement in criminal activities). The third topic, "good user care practices," seeks to reduce the possible tension caused by exploring the "user profile" and to determine the specific treatments and strategies that produce the most positive results from the perspective of the health providers. The last topic, "difficulties identified in the care process," seeks to determine whether the presence of organized crime represent a barriers to addiction prevention and treatment. Accordingly, the specific questions focused on the needs, challenges, difficulties, and risks faced by health providers in addiction prevention and treatment without asking questions directly about organized crime. The present study reports the results specifically related to barriers to addiction prevention and treatment.

\section{Procedures}

Eight semi-structured interviews were conducted, focusing on mental health professionals who undertake addiction prevention and treatment. Authorization was previously requested at the directorate of the corresponding institution to undertake the study, which was carried out in accordance with the principles of the Declaration of Helsinki and the Singapore Statement on Research Integrity. Since the institution where the study was conducted does not have an ethics committee, the study protocol was reviewed and approved by a researcher outside the study, a faculty member from a higher education institute in the state of Tamaulipas, with extensive experience in qualitative research on social phenomena in this state. Before the interviews were conducted, informed consent forms were handed out requesting the participants' authorization for audio recording. Participants were told that the purpose of the study was to find out about their experience in addictions care in order to obtain information that would make it possible to design an intervention on the basis of the difficulties found in their particular context. None of those contacted refused to participate or withdrew from the study.

The interviews were conducted between June 23 and August 21, 2015, at the primary care center, without the presence of people unrelated to the research project. One interview was conducted with each participant, with a duration of 60 to 90 minutes.

\section{Information analysis}

After the first interview had been completed and transcribed, a thematic analysis was carried out (Braun \& Clarke, 2006) using MAXQDA version 12 software. The researchers independently prepared transcript notes and created codes, and sub-codes that emerged from the data. They subsequently discussed the notes, codes, and sub-codes identified by each one. When the notes and codes were convergent and/or complementary, conceptual categories were drawn up that would account for the influence of organized crime in the addiction prevention and care activities. When the notes or codes did not tally, the researchers discussed the feasibility of creating a category derived from these codes and their importance in understanding the phenomenon studied. The process of triangulating researchers (Denzin, 1978) was carried out after each of the interviews had been completed.

When the researchers agreed that the information from the most recent interview analyzed failed to contribute anything new to the analysis categories constructed up to that point, it was decided that theoretical saturation had been achieved and that the field work had been completed. 


\section{Ethical considerations}

Interviews were conducted in a private cubicle within the primary care center, so that participants could express themselves freely.

They were not asked for personal data which could identify them. Folio numbers were assigned to the audio and text files, and the informed consent forms in which the purpose of the study was clearly explained. To enhance the security of the participants once the interviews had been transcribed, the audio files were deleted. Each transcript was exported to the MAXQDA software to be analyzed. The files created in a word processor with the transcript of each interview were deleted once they had been exported to MAXQDA. The authors of this paper have preserved the files of the MAXQDA program with the information analysis.

\section{RESULTS}

The data analysis yielded the following thematic axes: a) Influence of organized crime on the community; b) Barriers to addiction prevention; c) User care in a context of insecurity and; d) Strategies for the protection of health providers.

\section{A) Influence of organized crime in the community}

The health staff identified several interacting elements that facilitate the onset of use in adolescents. A first element is that use is determined by the substances criminal organizations distribute in the region ("it did not exist before, that is, the cartel used not to sell it but now it does", Participant 1). Another element is the availability of these substances, which can be purchased at the same schools where preventive activities are carried out:

I started giving talks and it was very common in middle school for students to show me the drug wrapped in sheets of paper... I have heard from the middle schools where I went to work, that the dealers are the ones who give them to them ... they have already identified the schools and they go and sell drugs there (Participant 3).

Onset of use may be associated with individual aspects such as the desire to experiment, but particularly with circumstances in the family context, such as financial difficulties, structure (affected by the separation of the couple or the absence of the father), or "dysfunctionality", which, for the participants implies the presence of violence or lack of parental supervision or limits. In the community sphere, another important element is the link with peers who use drugs. It is worth mentioning that this configuration of elements not only creates a context of vulnerability to substance use, but also to incorporation into criminal groups:

It is a financial problem, it is a very important problem, and it has to be dealt with... mothers have to work 12 to 18 hours to more or less take something home, which is why criminal groups are able to win young people over now... because they paint a picture of wonderful things and necessity forces them into it (Participant 6).

Although young people may engage in substance use without necessarily belonging to a criminal group, those who do join organized crime can be especially vulnerable to substance use:

There are patients who get involved (in crime) without being users, but they have to use drugs later on to do things (illicit acts)... they gradually take risks, they do not like drugs, they do not like the sensation, but they need them to be able to work (Participant 6).

\section{B) Barriers to addiction prevention}

The control of communities by organized crime encourages the construction of a scenario in which education authorities are afraid to address drug sale and use within schools for fear of reprisals:

Teachers' response is sometimes: We know what is going on, but we cannot get more involved, because there is also the fear that they may be involved and take reprisals (Participant 3).

Fear of these groups may restrict the implementation of prevention strategies in schools by health providers. This was initially expressed as the need to modify the way people talk about addictions:

Previously it was about being against addictions, but right now it is not against, it's about prevention, because if you said "against," it came across as very aggressive and since the insecurity and everything started, they started to refer to it like that...they changed the name a bit (Participant 7).

Participants report that they are afraid to go into certain schools, either due to the presence of members of organized crime in the surroundings or within the educational institution, as well as the possible negative connotation of their entry due to their position as government workers:

I did not want to go to schools anymore because we found out, for example, that there are halcones* at the school. We couldn't talk about them because they did not understand, they just know that we are on the other side... we started to take precautions, they started telling us not to wear government shirts inside schools (Participant 1).

At the same time, health providers perceive that preventive messages cannot always counteract the cultural influence of these organizations as regards the promotion of certain values and lifestyles:

I feel that drug trafficking has a lot of influence here because they regard it as the greatest thing: fast money, luxuries, SUVs, houses. Men think they will have many women, and that they will be attractive (Participant 4).

* Literally, "hawks", informers at the service of organized crime. 


\section{C) User care in a context of insecurity}

Clashes between criminal organizations or against security forces may occur within the community. At times, violent events may take place, threatening the integrity of both health providers and users:

There were also many shootings in the area and we had to leave. There were soldiers all around ... we were very scared, we were in therapy, and there were shootings going on (Participant 1).

Health providers can provide treatment to users who engage in criminal activities and also have problems with substance use. This situation usually generates concern for their personal safety:

Teenagers have turned up who, suddenly, in the initial interview, confess that they are halcones or are involved in organized crime in some way (Participant 3).

Care for users who engage in criminal activities can affect the conditions in which treatment is delivered, in terms of file registration, the continuity of the sessions, or the reason why they go to the center, since sometimes patients go to centers more to avoid legal problems than for the purpose of recovery.

They used to send them to us, they used to arrest them in the street and they sometimes argued that they had been arrested with drugs for their personal consumption, but when they got here we realized that they were dealers... Since the prosecutor's office said that, "We want to see you are going to a treatment"... Once one of them just turned up and said, "I just want you to sign the form for me, I'm not coming to therapy" (Participant 5).

As mentioned earlier, substance use can become part of life within organized crime. Although there are users who do not complete their treatment, health providers report that in some cases they reduce their use:

Most people within that organization do engage in some kind of use. I believe that no one in their right mind would do what they do... they want to recover and they want to stop using substances... which, of course, is much more difficult for them, but, I mean, they try, however they come at a time when they are beginning to recapacitate and they want to stop using. And yes, we do manage to stop them using... although they do not leave that environment (Participant 4).

Although the center is located in a place where confrontations related to criminal organizations or users who are involved in these organizations have taken place, there are no security providers:

The main risk is that I do not have... that I'm there in a highrisk area and that we do not have providers to protect us, that is, we do not have any providers for that (Participant 3).

\section{D) Health providers protection strategies}

Health providers have developed a series of measures to protect themselves during the care process. If a violent event occurs in the vicinity of the center, they can call the local authorities or close the institution until the event is over:

... sometimes we are forced, if a situation gets out of control, well, we talk to the soldiers or we talk to the $\mathrm{C} 4$ (Control Command, Computing and Communications Centers), for example, for them to come and supervise the area... you can also report to the headquarters and, in risky situations like this, they have asked us to close the facility (Participant 3 ).

When providing care for users who claim to be or have been involved in organized crime, participants report that they prefer "not knowing", in other words, having as little information as possible to protect themselves and not feel so involved:

I always tell them that I'm not interested in names, I'm not interested in places, I'm not interested in any of that... I mean, I just want to help... I do not want to know the details... I do not want to know that for safety... I always tell them I do not want to know names, places or details (Participant 4).

In addition to "not knowing", health providers can use other types of personal strategies, such as "not thinking" about the situation of the user who participates in organized crime, since this can affect the care process due to fear of the user or the discomfort caused by his or her activity:

I try not to think too much about that too... because then I feel like I'm not going to be able to do my job because I'll be on the defensive (Participant 5).

Another strategy to protect oneself is to modify schedules so that no care is given in the evenings, since it is thought that this is when there is a greater risk of violent events. In addition, they try to assign a special schedule for members of organized crime in order to attend them when there are more providers around.

For this type of case, appointments are given at two in the afternoon because all the morning and evening providers are present. So we feel slightly safer (Participant 2).

Likewise, when they have to perform an extramural activity in the community or simply at the end of their work day, health providers attempt to protect themselves by trying to go unnoticed:

Sometimes we do not go out wearing a white coat or uniforms... that also guarantees that you will not be identified when there has been a lot of insecurity... well, not in uniform, or with a ID badge, or anything (Participant 3).

In this scenario, some participants perceive that security is not guaranteed by the state, but by the control exercised by organized crime in the locality. In these circumstances, they need to protect the relationship they have with members of these groups:

At some point we already knew or needed to meet those involved in organized crime. It is not that you want to, but hey, they are people you have known for a long time. You cannot break off the friendship either because then you say what if we ever need them? So it is something that is very drastic in 
our life and everything is in their hands... and not the government's which is supposed to be... well, looking out for us, so it's everyone for themselves (Respondent 6).

\section{DISCUSSION AND CONCLUSION}

The power of organized crime is not only expressed in the possibility of determining the illicit substances that are distributed, but also in the ability to enter educational facilities and exercise control over communities, which is observed in the surveillance processes, fear of filing complaints on the part of educational institutions, and limitations on the ability of health providers to carry out preventive activities in these spaces.

The providers perceive that vulnerability to onset of use is linked to peer influence (Cleveland, Feinberg, Bontempo, \& Greenberg, 2008), which is a predictor for both beginning and continuing use until the beginning of adulthood. It is also facilitated by the lack of parental supervision, although Van Ryzin, Fosco, and Dishion (2012) have found that after the transition to high school, the quality of the relationship with parents plays a more important role, in terms of affection, trust, and communication. A third element that combines with the previous ones is the promotion of lifestyles associated with substance use, since this is facilitated by a positive attitude towards drugs and the lack of conformity with the moral order (Stone, Becker, Huber, \& Catalano, 2012). However, in developing countries, substance use has also become a form of escape from social suffering (Singer, 2008), especially in young people who have been excluded from educational and work opportunities (Azaola, 2012).

This context of vulnerability not only encourages substance use but also incorporation into organized crime. At the family level, alcohol consumption, low educational attainment of the head of household, or the absence of one of its members due to migration have been associated with the risk of a student engaging in drug trafficking (Vilalta \& Martínez, 2012). Likewise, family disintegration has been linked to attacks on the authorities by criminal organizations (Vilalta, 2013). At the same time, fascination with the accumulation of money, the quest for status, respect, and sexual relations, as well as the culture of drug use (Campbell \& Hansen, 2012), are factors that promote incorporation into drug trafficking, which, in turn, increases the risk of substance use (Li, Feigelman, Stanton, Galbraith, \& Huang, 1998).

A person may get out of organized crime during the process of treatment for substance dependence, since the person usually engages in drug use in order to carry out criminal activities, or performs these activities in order to continue using (Campbell \& Hansen, 2012). Treatment is crucial to the social rehabilitation of users who participate in organized crime. However, the results show that there are no programs or care policies to suit the needs of drug users with this profile, because accessing the service requires the user to respect treatment conditions and establish safety conditions for both the rest of the users and the staff at care centers. However, since there is no security in the community or the care center, for either the users or the health providers, treatments may be negatively affected. The same happens with prevention activities, since they are performed with extreme caution or fear on the part of health providers, who strive to ensure that their work does not disturb the groups engaged in crime.

The participants' accounts show a cultural process of normalization of the presence of organized crime (Campbell, 2005) in the communities where they work. In this respect, Bautista (2017) recommends the study of people's everyday practices and relationships since they reflect the long-term effects of violence. In the case of health providers immersed in a context of violence linked to organized crime, their everyday practices and relationships have been disrupted in several respects: for instance, in their journeys to work, where they may be victims of a certain type of crime because the neighborhood is dangerous. During the eight hours they work, either inside the center or when they engage in extramural activities, they face various risks, such as shootings and all kinds of confrontation between criminal groups, or even direct aggression targeting the center where they work, which may be regarded as the "enemy" of the trafficking of illicit substances, and users of the center may be attacked by criminal groups or rival cartels. During preventive activities at schools, health providers may be identified and assaulted by criminal groups and even by students belonging to these criminal organizations.

The feeling of insecurity (Kessler, 2011) experienced by health providers affects their mental health, causing stress, anxiety, depression, or aggression, reducing the quality of the service they provide and modifying their discourse regarding drugs and addictions. For now, health providers have learned to cope with this type of context by accepting the limitations imposed on preventive activities, adjusting treatment to the requirements of members of these organizations, and implementing various protection strategies such as "not knowing", "not thinking", "going unnoticed", modifying schedules or stopping activities when violent events occur. Vilalta (2013) has found a link between the deaths associated with confrontations and a process of institutional anomie, particularly associated with government weakness. This weakness also appears to manifest itself in the state's difficulty in reducing the control of territories by organized crime, preventing the distribution of substances in educational contexts, and guaranteeing the development of preventive activities and the safety of health providers.

It should be noted that the safety of health providers cannot be separated from the safety of the entire community. Accordingly, strategies and public policies must be re-thought and go beyond the use of public force; as men- 
tioned by Gledhill (2017). The use of armed force in Mexico in peacekeeping operations aimed at eradicating criminal violence has had negative consequences for the affected populations, since more violence is created.

Along this same line of thought, it is worth reflecting on the social determinants of health contemplated by the WHO (2009), which include the set of social, political, economic, environmental, and cultural factors that influence health. In the case of drug users who participate in criminal activities, this situation conditions their right to health, since there are social, political, and cultural factors that permeate discourses and practices, making access to health institutions difficult. Hence the importance of following the recommendations of the WHO (2009): work to improve the living conditions of populations, reduce the inequitable distribution of power, money and resources; and evaluate the scope of the problem by analyzing it and evaluating the effects of interventions. This paper seeks to contribute to this analysis and the understanding of organized crime as a social determinant of physical and mental health, as well as a barrier to addiction prevention and treatment.

It is important to mention certain limitations of the study, such as the temporal and spatial variations of the phenomenon of insecurity, since the findings only show what happens in a specific local context. Likewise, the situation of insecurity places restrictions on access to informants, either due to aspects such as censorship or the concern of informants and researchers about their integrity, given the uncertainty regarding the engagement of social actors in organized crime. Mention should be made of the need to include the voices of male providers and complement the perspective of health providers with that of both users and members of the communities and educational institutions.

Implications of the study include the need to link the prevention of substance use with the prevention of the incorporation into organized crime, and the need to establish strategies that counteract the influence of the values and lifestyles promoted by organized crime, especially in excluded social groups. It is also essential for the state to recover educational spaces and communities, and to guarantee safety conditions for addiction prevention and treatment.

\section{Funding}

This study was carried out as part of Project 1678 of the CONACYT Chair: "Development of capacities for addiction prevention through an intervention based on Family Resilience", directed by Dr. Anel Hortensia Gómez San Luis. No financing was provided.

\section{Conflict of interests}

The authors declare they have no conflict of interests.

\section{Acknowledgements}

Special thanks are due to the participants who were interviewed and shared their experience in the field of addiction prevention and treatment.

\section{REFERENCES}

Azaola, E. (2012). La violencia de hoy, las violencias de siempre. Desacatos, 40, 13-32.

Bautista, M. (2017). El murmullo social de la violencia en México. Ciudad de México: CESOP \& UAM.

Borges, G., Wang, P., Medina-Mora, M. E., Lara, C., \& Chiu, W. T. (2007). Delay of first treatment of mental and substance use disorders in Mexico. American Journal of Public Health, 97(9), 1638-1643. doi: 10.2105/AJPH.2006.090985

Braun, V. \& Clarke, V. (2006). Using thematic analysis in psychology. Qualitative Research in Psychology, 3(2), 77-101. Retrieved from: http://eprints.uwe. ac.uk/11735

Campbell, H. (2005). Drug trafficking stories: everyday forms of narco-folklore on the U.S. -Mexico border. International Journal of Drug Policy, 16(5), 326-333. doi: 10.1016/j.drugpo.2005.06.003

Campbell, H. \& Hansen, T. (2012). Getting out of the game: desistance from drug trafficking. International Journal of Drug Policy, 23(6), 481-487. doi: 10.1016/j. drugpo.2012.04.002

Charmaz, K. (2013). La teoría fundamentada en el siglo XXI. Aplicaciones para promover estudios sobre la justicia social. In N. K. Denzin \& Y.S. Lincoln (Eds.), Manual de investigación cualitativa volume III. Estrategias de investigación cualitativa (pp. 270-325). Barcelona: Gedisa.

Cleveland, M., Feinberg, M., Bontempo, D., \& Greenberg, M. (2008). The role of risk and protective factors in substance use across adolescence. Journal of Adolescent Health, 43(2), 157-164. doi: 10.1016/j.jadohealth.2008.01.015

Corbin, J. \& Strauss, A. (2008). Basics of qualitative research. Tecniques and procedures for developing grounded theory. California: Sage.

Denzin, N. (1978). The research act: A theoretical introduction to sociological methods. New York: Praeger.

Dulin, A. \& Patiño, J. (2014). The logic of cartel car bombings in Mexico. Trends in Organized Crime, 17(4), 271-289. doi: 10.1007/s12117-014-9230-z

Flick, U. (2004). Introducción a la investigación cualitativa. Madrid: Morata.

Gledhill, J. (2017). La cara oculta de la inseguridad en México. México: Paidós.

Gómez, A. \& Almanza-Avendaño, A. M. (2016). Impacto del narcotráfico en jóvenes de Tamaulipas, México: drogas e inseguridad. Revista de Psicología, 34(2), 445-472. doi: 10.18800/psico.201602.009

Guerrero, E., Villatoro, J. A., Kong, Y., Fleiz, C., Vega, W., Strathdee, S., \& Medina-Mora, M. E. (2014). Barriers to accessing substance abuse treatment in Mexico: a national comparative analysis by migration status. Substance Abuse Treatment, Prevention, and Policy, 9(30). doi: 10.1186/1747-597X-9-30

Hernandez, A. \& Grineski, S. (2012). Disrupted by violence: children's well-being and families' economic, social, and cultural capital in Ciudad Juarez, Mexico. Revista Panamericana de Salud Pública, 31(5), 373-379. doi: 10.1590/S102049892012000500004

Horigian, V., Espinal, P., Alonso, E., Verdeja, R., Duan, R., Usaga, I., ... Feaster, D. (2016). Readiness and barriers to adopt evidence-based practices for substance abuse treatment in Mexico. Salud Mental, 39(2), 77-84.doi: 10.17711/SM.01853325.2016 .004

Kessler, G. (2011). El sentimiento de inseguridad. Sociología del temor al delito. Buenos Aires: Siglo XXI.

Li, X., Feigelman, S., Stanton, B., Galbraith, J., \& Huang, W. (1998). Drug trafficking and drug use among urban African-American adolescents: A causal analysis. Journal of Adolescent Health, 23(5), 280-288.

Marín-Navarrete, R., Eliosa-Hernández, A., Lozano-Verduzco, I., Fernández-De la Fuente, C., Turnbull, B., \& Tena-Suck, A. (2013). Estudio sobre la experiencia de hombres atendidos en centros residenciales de ayuda mutua para la atención de las adicciones. Salud Mental, 36(5), 393-402. Retrieved from: http://www. scielo.org.mx/scielo.php?script=sci_arttext\&pid=S0185-33252013000500007

Natera, G., Mora, J., \& Tiburcio, M. (1999). Barreras en la búsqueda de apoyo social para las familias con un problema de adicciones. Salud Mental, 22, 114-120. Retrieved from: http://revistasaludmental.mx/index.php/salud_mental/article/ view/792

Nuño-Gutiérrez, B. L., Álvarez-Nemegyei, J., González-Forteza, C., \& Madrigal-de León, E. (2006). La adicción ¿vicio o enfermedad? Imágenes y uso de servicios de salud en adolescentes usuarios y sus padres. Salud mental, 29(4), 47-54. 
Retrieved from: http://www.medigraphic.com/pdfs/salmen/sam-2006/sam064g. pdf

Organización Mundial de la Salud (2009). Reducir las inequidades sanitarias actuando sobre los determinantes sociales de la salud. $62^{a}$ asamblea mundial de la salud. Documento A62/9. Retrieved from: http://apps.who.int/gb/ebwha/pdf_files/ A62/A62_R14-sp.pdf

Patton, M. Q. (1990). Qualitative evaluation and research methods. Newbury Park: Sage.

Reyes-Sosa, H., Larrañaga-Egilegor, M., \& Valencia-Garate, J. F. (2015). Dependencia representacional entre dos objetos sociales: el narcotráfico y la violencia. Cultura y representaciones sociales, 9(18), 162-186. Retrieved from: http:/ www.scielo.org.mx/scielo.php?pid=S2007-81102015000100006\&script=sci_arttext\&tlng=en

Richter-White, H. (2002). The direct and indirect impacts of organized crime on youth, as offenders and victims. Trends in Organized Crime, 7(4), 79-111. doi: 10.1007/s12117-002-1006-1

Rojas, E., Real, T., García-Silberman, S., \& Medina-Mora, M. E. (2011). Revisión sistemática sobre tratamiento de adicciones en México. Salud Mental, 34(4), 351-365. Retrieved from: http://www.scielo.org.mx/scielo.php?script=sci_arttext\&pid=S0185-33252011000400008

Romero, M., Saldívar, G., Loyola, L., Rodríguez, E., \& Galván, J. (2010). Inequidades de género, abuso de sustancias y barreras al tratamiento en mujeres en prisión. Salud mental, 33(6), 499-506. Retrieved from: http:/www.revistasaludmental.mx/index.php/salud_mental/article/view/1382/1380

Silva, R. (2004). Narcotráfico y economía ilícita: las redes del crimen organizado en Río de Janeiro. Revista Mexicana de Sociología, 66(1), 141-192. Retrieved from: http://www.scielo.org.mx/scielo.php?pid=S0188-25032004000100005\& script $=$ sci_arttext
Singer, M. (2008). Drugs and development: the global impact of drug use and trafficking on social and economic development. International Journal of Drug Policy, 19(6), 467-478. doi: 10.1016/j.drugpo.2006.12.007

Solar, O. \& Irwin, A. A. (2010). A conceptual framework for action on the social determinants of health. Social determinants of health discussion paper 2. Retrieved from: http://apps.who.int/iris/bitstream/10665/44489/1/9789241500852_eng. pdf

Stone, A., Becker, L., Huber, A., \& Catalano, R. (2012). Review of risk and protective factors of substance use and problem use in emerging adulthood. Addictive behaviors, 37(7), 747-775. doi: 10.1016/j.addbeh.2012.02.014

Van Ryzin, M., Fosco, G., \& Dishion, T. (2012). Family and peer predictors of substance use from early adolescence to early adulthood: an 11-year prospective analysis. Addictive behaviors, 37(12), 1314-1324. doi: 10.1016/j.addbeh.2012.06.020

Vázquez, L. D. (2012). Acercamiento estadístico a la realidad de los menores infractores en México: legislación y crimen organizado, nuevos desafíos. Universitas Psychologica, 11(4), 1105-1114. Retrieved from: http://www.scielo.org.co/ scielo.php?script=sci_arttext\&pid=S1657-92672012000400006\&lng=en\&n$\mathrm{rm}=\mathrm{iso} \& \mathrm{tlng}=\mathrm{es}$

Vilalta, C. (2013). Anomia institucional, espacialidad y temporalidad en las muertes asociadas a la lucha contra la delincuencia organizada en México. Estudios Mexicanos, 29(1), 280-319. doi: 10.1525/msem.2013.29.1.280

Vilalta, C. (2016). Does the mexican war on organized crime mediate the impact of fear of crime on daily routines?. Crime \& Delinquency, 62(11) 1448-1464. doi: $10.1177 / 0011128714541208$

Vilalta, C., \& Martínez, J. M. (2012). The making of Narco bosses: hard drug dealing crimes among Mexican students. Trends in Organized Crime, 15(1), 47-63. doi: 10.1007/s12117-011-9144-y 